\title{
Policy Direction for AHP-Based Disaster Mitigation Education the Post Eruption of Dempo Volcano in Pagar Alam City - Indonesia
}

\author{
Irda Suryani, Dedi Hermon, Eri Barlian, Indang Dewata, Iswandi Umar
}

\begin{abstract}
This research is backed by the lack of attention of the government in the world of education against the risk of Post eruption of Dempo volcano in Pagar Alam City in the form of preparation and socialization of disaster mitigation measures, evacuation pathways provided, early warning systems in the volcano disaster-prone areas. On the other hand, with disaster preparedness, damage and victim numbers can be minimized. The purpose of this research is to formulate a priority referral education mitigation of the eruption of post-eruption of Dempo volcano. Data collection using relevant interviews, observations and information collection. Then the data is grouped by hazard level criteria, vulnerabilities, and risks that may arise. Data is processed with assessment and analysis with the Analytical Hierarchy Process (AHP). Research findings suggest that the priorities of disaster mitigation education of post-eruption of Dempo volcano are as follows: the measurable and periodical aspects of training and disaster simulation (0.832), coordination and cooperation in anticipating disasters of (0.813), human resources amounting to $(0.801)$, routes and evacuation sites amounting to (0.799), and early warning systems of (0.795).
\end{abstract}

Keywords: policy, education, mitigation, dempo volcano.

\section{INTRODUCTION}

Indonesia is an archipelago country with a high-intensity volcanic disaster because the geographical location of Indonesia is located in the path of Ring of Fire [1-3]. Formed Ring of Fire area in Indonesia is due to the Eurasian Plate meeting in the north, the Australian plate of India in the South and the Pacific Plate in the East [4]. Indonesia itself has 127 active volcanoes or about $13 \%$ of the world's Active mountain, comprising 76 types A volcanoes, 30 type B volcanoes that is the Dempo volcano. Dempo volcano is a

Revised Manuscript Received on May 15, 2020.

* Correspondence Author

Irda Suryani*, his/her Department of geography and doctoral program of environmental science, Universitas Negeri Padang, Padang, Indonesia. Email: irdasuryani11@gmail.com

Dedi Hermon, Department of geography and doctoral program of environmental science, Universitas Negeri Padang, Padang, Indonesia. Email: dihermon006@gmail.com

Eri Barlian, Department of doctoral program of environmental science, Universitas Negeri Padang, Padang, Indonesia. Email: eribarlian@unp.ac.id

Indang Dewata, Department of doctoral program of environmental science, Universitas Negeri Padang, Padang, Indonesia. Email: indangdewata@fmipa.unp.ac.id

Iswandi Umar, Department of geography and doctoral program of environmental science, Universitas Negeri Padang, Padang, Indonesia. Email: iswandi_u@yahoo.com

(c) The Authors. Published by Blue Eyes Intelligence Engineering and Sciences Publication (BEIESP). This is an open access article under the CC BY-NC-ND license (http://creativecommons.org/licenses/by-nc-nd/4.0/) volcanoes, and 21 type $C$ volcanoes [5-8]. One of the active

part of a volcanic belt located in South Sumatra - Indonesia, precisely in Lahat Regency and Pagar Alam City, South Sumatera Province [9].

Post eruption of Dempo volcano, activity in recent years has always shown its activities. The results of monitoring post-party observation of Post eruption of Dempo volcano Central Volcanology and mitigation of geological disasters the Ministry of Energy and Mineral Resources (ESDM) in Lahat district revealed that Post eruption of Dempo volcano has been raised to be wary since September 2009 same as Kaba volcano in Rejang Lebong Regency of Bengkulu Province because of the increased volcanic activity [10].

The aspect of the vulnerability includes physical, economic, social and environmental aspects [11-13]. Post eruption of Dempo volcano level is divided into three levels of disaster-prone area (KRB), i.e: KRB I at a radius of 1-2 $\mathrm{KM}, \mathrm{KRB}$ II at a radius of $2-5 \mathrm{KM}$, and KRB III at a radius of 5-8 KM [14]. Based on the results of the observation area that belongs to disaster-prone areas I include Tanjung Sakti Sub-district Lahat Regency, and disaster-prone areas II and III covers sub-district of North Dempo, South Pagar Alam and Kota Agung in Pagar Alam City. In the 4th Sub-district, There are settlements, public facilities, productive land, and protected forest. This area is thus an area that is physically, socially, environmentally and economically vulnerable.

As a disaster-prone area, disaster mitigation is necessary to reduce losses caused by disasters [2]. In this case, the local Government of Lahat Regency and Pagar Alam City has the obligation and responsibility in anticipating catastrophe before or after the disaster. Mitigation is generally interpreted as all measures taken to minimize the impact of a disaster on, whether it is casualties and/or losses of property that will affect human life and activities, [15]. Disaster mitigation can reduce the worst risk in the event of a disaster [2].

The lack of optimal role of government and education to disaster mitigation the post-eruption of Dempo volcano, such as preparations, socialization of disaster mitigation measures, evacuation pathways provided, and early warning systems in the area of Dempo volcano resulted in the disaster mitigation not running properly. Therefore, it is necessary to do a study on the priority direction of disaster mitigation education policy in both schools and communities in the Dempo volcano region.

Increased volcanic earthquake activity normally only 200 to 300 times months. But it rose to 350 times in September 2009, and now rises again to 1,130 times in October. The volcanic earthquake of November was 852 times, and most in December 2009 as many as 2,044 times.

\section{Published By:}

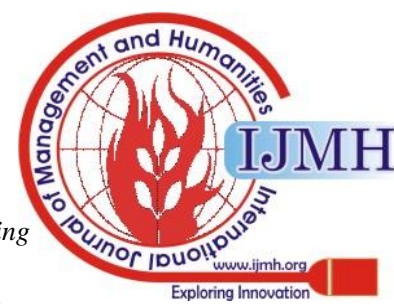




\section{Policy Direction for AHP-Based Disaster Mitigation Education the Post Eruption of Dempo Volcano in Pagar Alam City - Indonesia}

Since January 2010 the earthquake activity recorded as many as 674 times, February as many as 802 times, March at 860, in April decreased to 217 times. Furthermore, in May increased again by 588 times, June as much as 349 times, July as much as 306 times, August began to decline to 226 times and September 2010 only 148 times [16].

\section{RESEARCH METHODS}

Data is collected using interviewing techniques, observations and collecting relevant information. Interviews are conducted privately, directly, and unstructured. The method of interviewing is in-depth interviews by digging in-depth, open, and free with problems and research-focused and directed at the research centre [17]. The interview aspects that can be planned are objectives, questions, settings, and reactions to the specific problems [16]. Data collection using a purposive sampling technique $[17,16]$, with the criteria of the party that can to provide information about the education directions mitigation of Post eruption of Dempo volcano. The Regional Disaster Management Agency (BPBD) of South Sumatera Province, regional disaster Management Agency (BPBD) Lahat Regency, PVMBG, community leaders, schools became the unit of education and community in the area of disaster-prone eruption.

The Data that has been collected is grouped by hazard, vulnerability and risk level criteria. The results are then scoring and analyzed with AHP which uses the application of the Criterium 3.0 decision Plus. AHP measurements are done by building a scale or in the form of a specific index, scoring, or numerical value $[5,19]$. The steps that must be passed on the AHP approach include: a) Hierarchical drafting, to outline the issue of being elements in the form of alternative criteria compiled in hierarchies; b) Drafting criteria used to make decisions equipped with alternative forms related to each of these criteria to be selected as a decision is listed at the bottom of the level; c) Assessment of criteria and alternatives, to see the strategic influence on achieving goals assessed through pairs comparison. Values and definitions of qualitative opinions based on comparison scales; and d) Determination of priorities, using pairs comparison techniques (Pairwise Comparisons) for each alternative criterion. The relative comparison values are processed using matrix manipulation or through the completion of mathematical equations to determine the relative rank and all existing alternatives. Further calculation is done to see the assessment consistency by using the calculation Inconsistency ratio.

Table-1 Assessment criteria in AHP

\begin{tabular}{cl}
\hline Values & \multicolumn{1}{c}{ Descriptions } \\
\hline 1 & Equal important \\
3 & Moderate important \\
5 & Strong important \\
7 & Very strong important \\
9 & Extrem important \\
$2,4,6,8$ & Intermediate values \\
\hline
\end{tabular}

Source : $[5,19]$

\section{RESULT}

The Education policy directive criteria for Post eruption of Dempo volcano is created 10 alternate policies that are drawn in the policy hierarchy (Fig 1). Here is an alternative policy for mitigation of post-eruption of Dempo Volcano in Pagar Alam City.

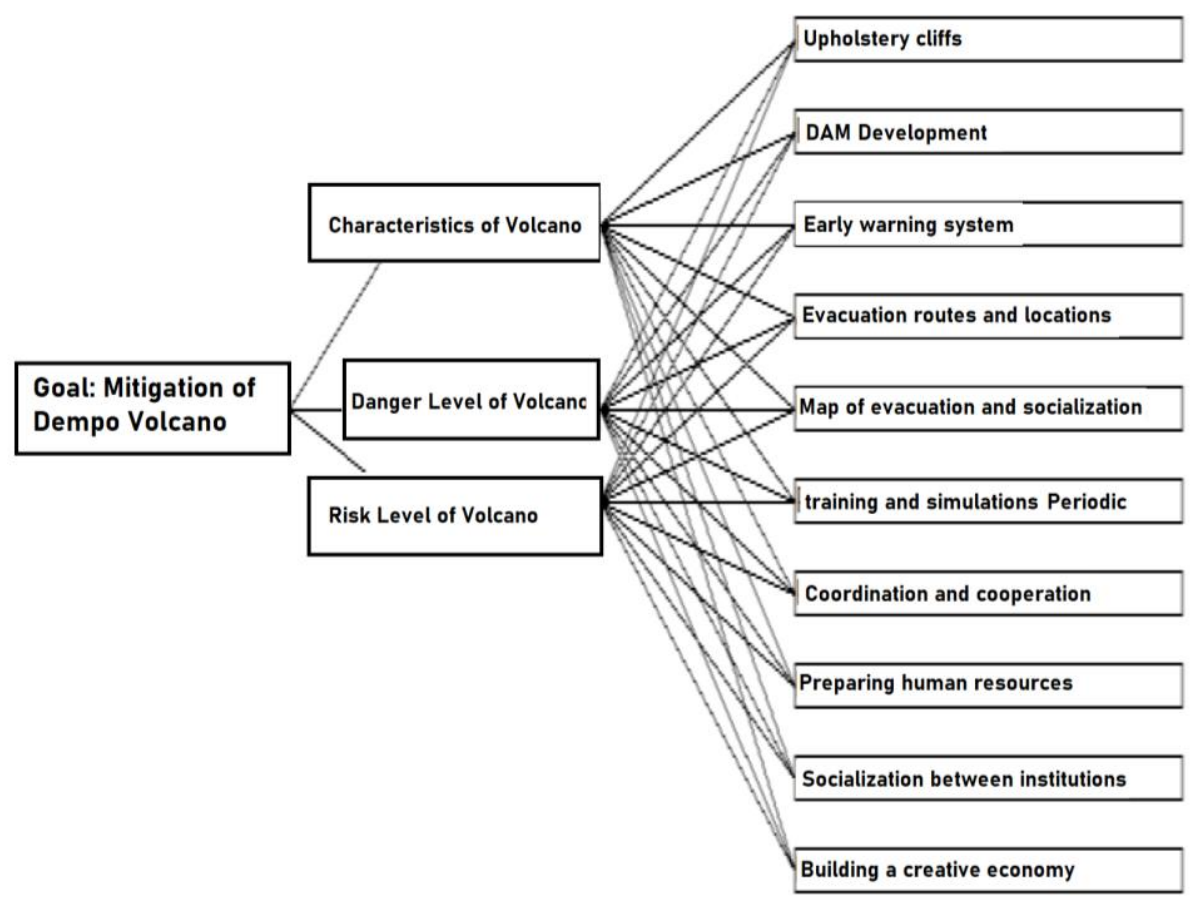

Fig 2. Policy Hierarchy of Dempo Volcano Mitigation

Calculation consistency ratios are obtained from the data consistency calculation result between criteria with alternate policy based on policy hierarchy. The value of the Consistency ratio obtained is 0.025 (below from 0.1 ). The value explains that the data used to make the formulation of the education policy mitigation of Post eruption of Dempo volcano is consistent so that the data can be used.

Published By: Blue Eyes Intelligence Engineering \& Sciences Publication

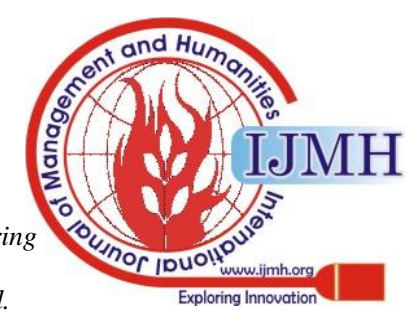




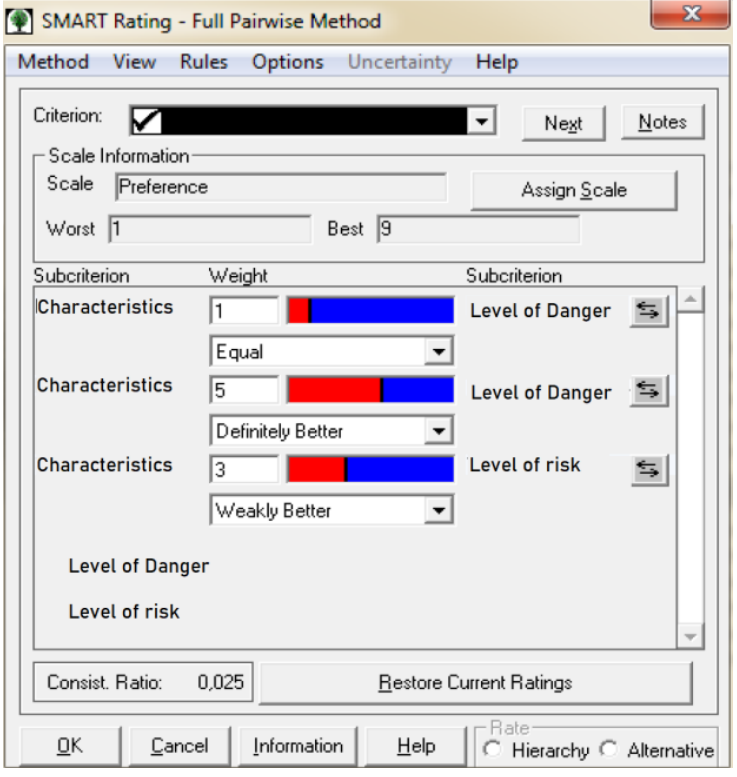

Fig 3. Value of consistency ratio

Once the data is known to be consistent, from ten alternative policies can be taken 5 policy priorities. Five policies that can be taken care measurable and periodic training and disaster simulation (0.832), coordination and cooperation in anticipating disasters (0.813), preparing human resources (0.801), evacuation lines and places (0.799), and early warning systems (0.795).

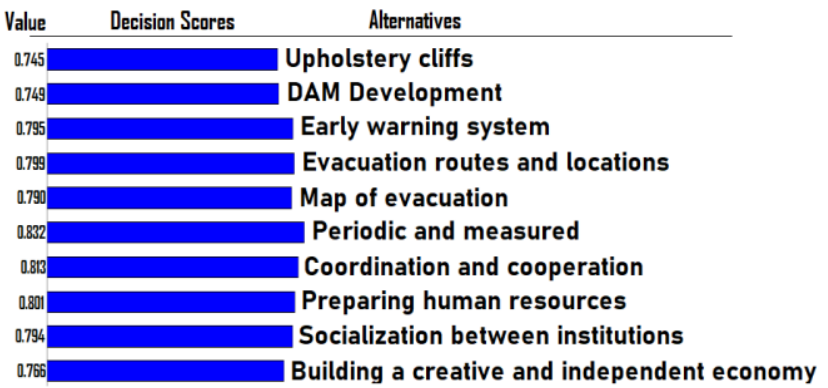

Fig 3. Priority education Policy mitigation Post eruption of Dempo volcano

The policy priority can be carried out with the implementation and implications of each policy. The implementation and implications of each of the priorities of the policy are as follows:

1. Education policy on the mitigation of mountain eruption with a mountain characteristic approach

a. Cliff coatings: Cliff coatings need to be made to reduce the impact of landslides on the slopes of the mountain when there is an eruption. The construction of the cliff coatings is constructed by a slope of a vulnerable mountain.

b. DAM Development: The DAM development is a way to reduce the impact of pyroclastic flow resulting from mount eruption so that the effects posed such as lava floods and flash floods can be reduced. This DAM needs to be built in a river area located in the Post eruption of Dempo volcano area.

2. Education policy for mountain eruption mitigation with the hazard level aspect approach.

a. Early Warning System: Disaster early warning system is an important aspect of disaster mitigation system as it is a starting point for disaster-emergence awareness [20]. Early warning systems must be made to prepare the community in disaster emergencies. The early warning system should be done as follows.

- The early warning system is based and centred on the education sector (schools) and the community.

- Early warning system to reach the entire community (via radio, TV, telephone, technology tools, etc.).

- The message of early warning systems can be understood by all walks of life.

- Early Warning System provides complete/detailed event info and appropriate local needs.

- Early warning system based on education and community knowledge according to the type of disaster and risk, signal warning and community understanding of the overall warning and action to be taken by society.

- Community organizations can act on early warning messages and mobilize communities to act.

- The community believes in the early warning system and the organization that issued the early warning.

- Technical resources (monitoring and communication equipment), installed with a good system with personnel trained for maintenance and operation.

On Post eruption of Dempo volcano, should be made early warning systems in residential areas that are vulnerable to the risk of mountain eruption.

b. Routes and evacuation areas: trails and evacuation areas are needed in the event of a disaster, so it needs to be prepared. In this case, should the local government invite the Community institutions to cooperate in preparing them? Not only that, in determining the path and evacuation place should be made with the correct calculation so that the route and evacuation areas can be used during emergencies.

c. Track map and evacuation site and its socialization: Map formulation is important in disaster mitigation [21]. The formulation of the track map and evacuation site is indispensable to display the picture where the direction must be passed and the destination is safe in the event of an eruption. But it is also necessary to socialize about this map so that people can know and understand the route and the evacuation site.

3. Volcano disaster mitigation policy with risk-level aspect approach

a. Periodic and measurable training and disaster simulation (school and Community Environment): training and simulation should be done to prepare the community in the face of disaster, training and disaster simulation should be done by the community in a regular period as each village is at least training and simulation facing disaster $1 \mathrm{x}$ in a month or $1 \mathrm{x}$ in two months. This periodical is required for people to be trained and better prepared in the face of disaster.

Published By:

Blue Eyes Intelligence Engineering \& Sciences Publication

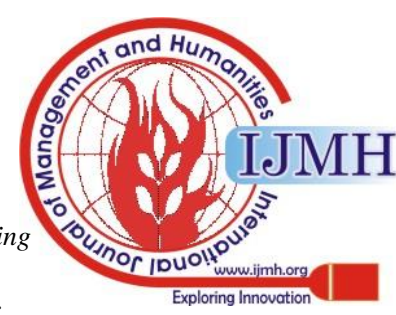


Then required evaluation in each training and simulation activities so that training and simulation are more effective and can improve the training and further simulation.

b. Coordination and cooperation in anticipation of disaster: working together in preparing and anticipating disaster is very necessary, people should cooperate with local governments to make preparations by preparing facilities and tools that support disaster mitigation, preparing evacuation routes, socialization, training and disaster simulation, etc. Besides, coordination and the work of the copulate clarifies tasks, functions, and responsibilities so that all work does not overlap.

c. Preparing human resources based on the local community: Human resources are indispensable for the implementation of mitigation, with the existence of human resources in this matter, the community can be guided in preparing disaster management. Preparing human resources based local community is a development or increase capacity of local communities such as indigenous people, community leaders, Coral Taruna and others. Following the opinions [22] Such empowerment can be initiated from Community institutions, especially youth institutions because youth are the next generation who will be faced with disasters. Things that can be done is to provide counselling to the community about the mitigation, conduct training related to disaster relief, and socialization of disaster mitigation.

d. Socialization between institutions that are related in disaster mitigation: dissemination can be implemented by developing cooperation with related agencies such as the Regional Disaster Management Agency, the National Agency for Disaster Relief, Public works, Indonesian Red Cross, Office of Health, BVMBG, local government and others. This effort aims to establish and improve the capacity of disaster management agencies and related agencies in the central and local areas in the face of pre-disaster situations, during emergency response and post-disaster recovery. Coordination and cooperation will also be increased between government agencies and personnel and all stakeholders in realizing reliable disaster management.

e. Building a creative and independent community economy: a self-sufficient economic community needs to be needed so that the community is not very dependent on the government during the pre-disaster or post-disaster. The things that can be implemented are as follows:

- Improving the quality of human resources in rural areas through various activities (education \& Training) and technology (technical guidance) in all fields.

- Community Empowerment strategy The empowerment process that emphasizes the process of giving people the ability to be empowered, encourage or motivate individuals to have the ability or power to determine their choice of life.

Empowerment of potential village needs to be done continuously by photographing the potential already owned and able to be developed continuously, whether agriculture and livestock become potential, both areas must be the flagship for the rural economy.

\section{CONCLUSION}

In this research criterion, the direction of the mitigation education policy that needs to be done is the policy direction and mitigation on the knowledge aspects of volcano characteristics, hazard level and risk level. The top 5 policy priorities of the ten criteria for mitigation policy referrals are measurable and periodic training and disaster simulation (0.832), coordination and cooperation in anticipating disasters (0.813), preparing human resources (0.801), evacuation routes and places (0.799), and early warning systems (0.795). The first prioritized is conducting measurable and periodical training and disaster simulation. Then the second priority by coordinating and working together in anticipation of disaster facing. Then the third priority is to prepare human resources, therefore human resources are indispensable to guide the community in preparing disaster management well. Furthermore, the fourth priority of the evacuation route should be prepared with a good calculation, so that people can use this path in an emergency. The last priority is an adequate early warning system, it is made to warn the community in disaster emergencies.

\section{ACKNOWLEDGEMENT}

This research can be carried out smoothly, because of the help and cooperation of various parties. Therefore, the author would like to thank the Government of Pagar Alam City who has provided the time to sharpen the academic ability us, especially in the field of disaster mitigation education of the eruption volcano.

\section{REFERENCES}

1. L. De Priester, An approach to the profile of disaster risk of Indonesia. Emergency and Disaster Reports, Vol. 3, Issue. 2, pp.1-66, 2016.

1. D. Hermon, Mitigation and Adaptation: Disaster of Climate Change. Sara Book Publication. India, 2019

2. D. Hermon, Evaluation of physical development of the coastal tourism regions on tsunami potentially zones in Pariaman City-Indonesia. International Journal of GEOMATE, Vol. 17, Issue. 59, pp. 189-196, 2019

3. D. Hermon, Geografi Bencana Alam. Penerbit: RajaGrafindo Persada, Jakarta, 2015

4. D. Hermon, Ganefri, Erianjoni, Dewata, I., Iskarni, P and Syam. A. A Policy Model of Adaptation Mitigation and Social Risks The Volcano Eruption Disaster of Sinabung in Karo Regency-Indonesia. International Journal of GEOMATE, Vol.17, No.60, pp190-196. 2019

5. A. Harris, Thermal remote sensing of active volcanoes: a user's manual. Cambridge university press, 2013

6. B. Voight, E.K. Constantine, S. Siswowidjoyo and R. Torley, Historical eruptions of Merapi volcano, central Java, Indonesia, 1768-1998. Journal of Volcanology and Geothermal Research, Vol. 100, Issue. 1-4), pp. 69-138, 2000

7. C.J. Horwell and P.J. Baxter, The respiratory health hazards of volcanic ash: a review for volcanic risk mitigation. Bulletin of volcanology, Vol 69, Issue. 1, pp. 1-24, 2006 
8. S. Teriawan, Analisis Pengaruh Gempa Tektonik Terhadap Aktivitas Gunungapi Dempo di Kota Pagar Alam Berdasarkan Data Seismisitas (Doctoral dissertation, Fakultas MIPA. UNIB). 2014

9. I.D. Putra, F.H. Akhyar and S. Husein, The Schematic Geotourism Sector Development Plan As An Approach To Increase The Regional Welfare As Well As To Create Regional Sustainable Development Of Rejang Lebong-Kepahiang District, 2014

10. I. Umar, I. Dewata and E. Barlian, Konsistensi Rencana Tata Ruang Permukiman dan Arahan Kebijakan Pembangunan di Kabupaten Tanah Datar, Provinsi Sumatera Barat. Journal of Natural Resources and Environmental Management, Vol. 9,Issue. 2, pp. 277-286. 2019

11. E. Barlian, Sumberdaya Energi Alternatif Dalam Pengembangan Berkelanjutan. IKIP Padang, 1991

12. I. Dewata, Distribusi Logam Pb, GAS SO2 dan NO2 di Udara Pada Ruas Jalan-jalan Utama Kotamadya Padang Sumatera Barat. UNP Padang, 2000

13. Badan Nasional Penanggulangan Bencana (BNPB), Baseline kegunungapian Indonesia. 2012

14. D. Hermon, Mitigasi Bencana Hidrometeorologi: Banjir, Lonsor, Ekologi, Degradasi Lahan, Puting Beliung, Kekeringan. UNP Press. 2012

15. J.F. Balliett, Oceans: Environmental issues, global perspectives. Routledge, 2014

16. E. Barlian, Metodologi Penelitian Kualitatif \& Kuantitatif. UNP Press, 2018

17. L. Arlym, D. Hermon, D. Lanin, O. Oktorie and A. Putra. A Policy Model of Preparedness The General Hospital in Reducing Victims of Earthquake and Tsunami Disasters in Siberut Mentawai Island, Indonesia. International Journal of Recent Technology and Engineering (IJRTE). Vol. 8. Issue 3. 2019

18. I. Basak and T. Saaty, (1993). Group decision making using the analytic hierarchy process. Mathematical and computer modelling, Vol.17, Issue. 4-5, pp.101-109

19. D. Hermon, Dinamika Permukiman dan Arahan Kebijakan Pengembangan Permukiman pada Kawasan Rawan Longsor di Kota Padang. Disertasi. IPB Bogor, 2009

20. A. Putra and H. Mutmainah, The Mapping of Temporary Evacuation Site (TES) and Tsunami Evacuation Route in North Pagai Island, Mentawai Islands Regency-Indonesia. IOP Conference Series: Earth and Environmental Science, 47(1), pp. 012020, 2016

21. D. Hermon, A. Putra and O. Oktorie, Characteristics of Melanic Epipedon Based on Biosequence in The Physiography of Marapi-Singgalang, West Sumatra. IOP Conference Series: Earth and Environmental Science. Vol. 314. Issue 1. 2019

\section{AUTHORS PROFILE}

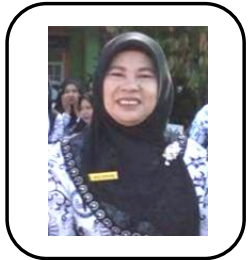

Irda Suryani is a Environmentalists and Teacher of High school Lintau Buo - Tanah Datar Regency, obtained the Master Degree in Management at STIE-KBP Padang. He is actively involved in any researches dan instruction regarded to environmental education and produces several scientific works in the form of journals and teaching materials. Right now he is a student Doctoral Program of Environmental Science, Universitas Negeri Padang and as Head of High School of 02 Lintau Buo, Tanah Datar Regency - West Sumatra Province.

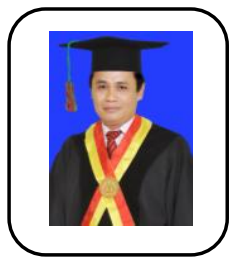

Dedi Hermon is a Professor of Disaster Geography, obtained the Doctorate Degree in Doctor Program Natural Resources Management and Environment at Bogor Agriculture University, 2009. He is actively involved in any researches regarded to natural disaster, land cover, carbon stock and produces several scientific works in the form of Scopus indexed journals (ID: 57200409691) and scientific books both national and international publications. He is assistant director of Postgraduate Universitas Negeri Padang as well as the head of Study Center of Disaster and Environment, Universitas Negeri Padang.

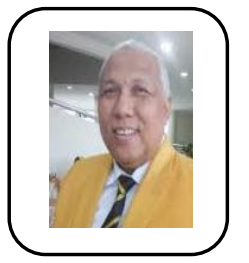

Eri Barlian is a Professor of Environmental Education, obtained the Doctorate Degree in Doctor Program Education Science at Universitas Neger Jakarta, 1999. He is actively involved in any researches regarded to environmental education, sports, recreation and disaster and produces several scientific works in the form of Scopus indexed journals (ID: 57202293479). He is Chair of Doctoral Program of Environmental Science, Universitas Negeri Padang.

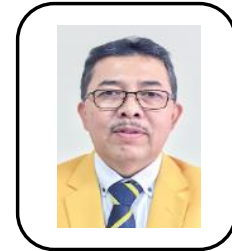

Indang Dewata is an Associate professor of Environmental Science, obtained the Doctorate Degree in Doctor Program Education Science at Universitas Indonesia, 2009. He is actively involved in any researches regarded to environmental science, chemical and produces several scientific works in the form of Scopus indexed journals (ID: 57202287960). He is Chair of Masters Program of Environmental Science, Universitas Negeri Padang.

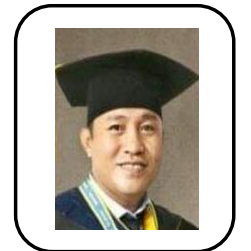

Iswandi Umar is an Associate professor of Environmental Science, obtained the Doctorate Degree in Doctor Program Natural Resources Management and Environment at Bogor Agriculture University, 2015. He is actively involved in any researches regarded to environmental science, geography and produces several scientific works in the form of Scopus indexed journals (ID 57204825796). He is Chair of Masters Program of Geography Education, Universitas Negeri Padang. 